\title{
Language barriers to studying medicine in English: perceptions of final-year medical students at the Arabian Gulf University
}

\author{
Yasin Tayem, ${ }^{1}$ Ahmad AlShammari, ${ }^{2}$ Nouf Albalawi ${ }^{2}$ and Marwa Shareef ${ }^{2}$
}

${ }^{1}$ Department of Pharmacology and Therapeutics, College of Medicine and Medical Sciences, Arabian Gulf University, Manama, Bahrain. ${ }^{2}$ College of Medicine and Medical Sciences, Arabian Gulf University, Manama, Bahrain. (Correspondence to: Yasin I. Tayem: yasiniyt@agu.edu.bh).

\begin{abstract}
Background: English is the language of instructions in many medical schools in the Arab world. Its use may create a language barrier and adversely affect an individual's learning and later professional life.

Aims: This study examined the views of final-year Arab medical students of a language barrier and its effect on their learning and academic performance, and their language preference for medial education.

Methods: All final-year medical students ( $n=142,62 \%$ females) at the Arabian Gulf University, Bahrain, were invited to respond to a self-completed questionnaire. Differences in responses according to English proficiency and sex were assessed.

Results: Of the 142 students, 99 (70\%) responded. Most students did not feel a language barrier irrespective of their proficiency in English $(P=0.088)$. Most respondents did not think that language issues made studying more difficult, although there was a significant difference in responses between students considered proficient in English and those less proficient $(P=0.005)$. Most students $(82 \%)$ were not aware or were not sure of medical terms in Arabic, but $66 \%$ were confident that they would be able to communicate with patients in Arabic. About half of the students (51\%) supported medicine being taught only in English and 36\% supported teaching in Arabic and English.

Conclusions: Most students thought that learning in English did not affect their academic learning and performance. However, a good proportion supported being taught medicine in Arabic and English.

Keywords: language, learning, medical education, academic performance, Arab world

Citation: Tayem Y; AlShammari A; Albalawi N; Shareef M. Language barriers to studying medicine in English: perceptions of final-year medical students at the Arabian Gulf University. East Mediterr Health J. 2020;26(2):232-237. https://doi.org/10.26719/2020.26.2.233

Received: 12/02/18; accepted: 16/04/18

Copyright (c) World Health Organization (WHO) 2020. Open Access. Some rights reserved. This work is available under the CC BY-NC-SA 3.0 IGO license (https://creativecommons.org/licenses/by-nc-sa/3.o/igo).
\end{abstract}

\section{Introduction}

All medical schools in countries of the Gulf Cooperation Council (GCC), including the Arabian Gulf University in Bahrain, use English as language of instructions for teaching undergraduate medical students whose first language is Arabic (1). The use of a second language for medical education may create a language barrier particularly for students for whom the second language was not taught or practised much during the first few years of their school education $(2,3)$. The most vulnerable students are those accepted for admission to medical colleges from governmental schools where teaching is mainly done in Arabic. Indeed, it has been reported that language difficulties were considered the second most important problem faced by medical students during their first year of study in a Saudi Arabian medical school (4).

The reason why a language barrier adversely affects learning is related to the limitation of working memory when learning is carried out in a second language (5). In addition, brain activation and information processing are more complex when teaching is conducted in a second language (6). An investigation into the sequence of activation of different parts of the prefrontal cortex in response to first (native) and second languages found that the anterior part of the right dorsolateral prefrontal cortex and the left superior temporal gyrus were activated when tasks were executed in the native language (5). However, when the same tasks were performed in the second language, the posterior part of the right dorsolateral prefrontal cortex and the left inferior temporal gyrus were activated. The left inferior temporal gyrus are shown to have lower proficiency in working memory and are therefore expected to result in superficial learning (5).

Students accepted for admission to the College of Medicine and Medical Sciences of the Arabian Gulf University in Bahrain are required to achieve excellent scores in high school, pass a written science test and undergo an interview (6). Since English is the language of instruction in the college, accepted students must pass a stringent English test before starting the preclinical phase of the programme (6). Candidates who have inadequate English skills are admitted to a foundation programme where they receive intensive English teaching over one academic year. Those who successfully pass the English test are directly admitted to the first year of the medical programme. 
In this study, we examined perceptions of finalyear medical students at the Arabian Gulf University of a potential language barrier and its effect on their academic performance and ability to adapt and manage the difficulties of the language barrier during the different phases of the medical programme.

\section{Methods}

\section{Study design and setting}

This was a cross-sectional study which conducted from January to March 2017 at the Arabian Gulf University in Bahrain.

\section{Participants}

All participants were final-year medical students (sixth year of study) during the academic year 2016-2017. Participants were expected to graduate at the end of that academic year. All students in the target cohort were Arabs from different GCC countries. They had all gone through the same admission process and experienced the same curriculum, which was almost completely taught in English.

All 142 medical students (62\% females) were invited to respond to a self-administered questionnaire. The students were approached in person by the investigators at the university and were asked to complete a hard copy of the questionnaire. Information was collected on student's sociodemographic data, language of school education and admission to the foundation year before starting the medical programme. Information on the possible effects of language difficulties on students' adaptation and ability to manage the difficulties of the language barrier and academic achievement in the different phases of the programme was sought. The survey used a five-point Likert scale to record responses on a number of statements (strongly disagree, disagree, not sure, agree and strongly agree). A pilot study was done with 10 students in their fifth-year of study, to validate the questionnaire. In order to categorize participants according to their proficiency in English, we relied on whether they had done a foundation year. Students who had done the foundation programme were considered to have inadequate proficiency in English; those who had not were considered to have adequate proficiency in English. We assessed the association between students' responses to the different items of the questionnaire and their placement on the foundation programme.

\section{Statistical analysis}

SPSS, version 23 was used for statistical analysis. The association between placement in the foundation year, as a measure of participants' proficiency in English, and responses to the survey questions was assessed by the Pearson chi-squared test. Differences between male and female responses were assessed using the Mann-Whitney test.

\section{Ethical considerations}

Ethical approval for this study was obtained from the Research and Ethics Committee at the Arabian Gulf University. Prior to participation, written informed consent was obtained from the students.

\section{Results}

Of the 142 final-year students, 99 (70\%) responded (56 females and 37 males; 6 did not indicate their gender). The participants came from four GCC countries: Saudi Arabia, Kuwait, Bahrain and Oman. Most participating students had not done the foundation year (78\%), although for $81 \%$, their teaching materials during school were in Arabic (Table 1).

Table 2 shows the students' perception of a language barrier during their medical education programme. Most students did not feel language barrier during their study. This finding was not significantly associated with their proficiency in English $(P=0.088)$. However, while most students did not think that the language barrier made studying more difficult, there was a statistically significant difference in the responses between students who had done a foundation year and those who had not $(P=0.005)$. The majority of the students did not believe that learning in English made studying less enjoyable, made adapting to studying medicine more difficult, or adversely affected their participation in class activities or examination performance; there was a statically significant difference in the responses between students who had done a foundation year and those who had not $(P<0.05$ for all these items). Most of the students were either not aware of medical terms in Arabic or not sure of them ( $47 \%$ and $35 \%$ respectively) but most were confident to take a medical history from patients in Arabic (72\%) and

\begin{tabular}{|c|c|}
\hline \multicolumn{2}{|c|}{$\begin{array}{l}\text { Table } 1 \text { Characteristics of the participating students at the } \\
\text { Arabian Gulf University and their exposure to English }\end{array}$} \\
\hline Characteristic & No. (\%) \\
\hline \multicolumn{2}{|l|}{$\operatorname{Sex}(n=93)$} \\
\hline Male & $37(40)$ \\
\hline Female & $56(60)$ \\
\hline \multicolumn{2}{|c|}{ Teaching materials during school education were mainly in $(n=99)$ : } \\
\hline Arabic & $80(81)$ \\
\hline English & $19(19)$ \\
\hline \multicolumn{2}{|c|}{ I did a foundation year at the Arabian Gulf University ( $n=99)$ : } \\
\hline Yes & $22(22)$ \\
\hline No & 77 (78) \\
\hline \multicolumn{2}{|l|}{ Nationality $(n=97)$} \\
\hline Saudi Arabia & $35(36)$ \\
\hline Kuwait & $31(32)$ \\
\hline Bahrain & $29(30)$ \\
\hline Oman & $2(2)$ \\
\hline United Arab Emirates & $0(0)$ \\
\hline Qatar & $\mathrm{o}(0)$ \\
\hline
\end{tabular}




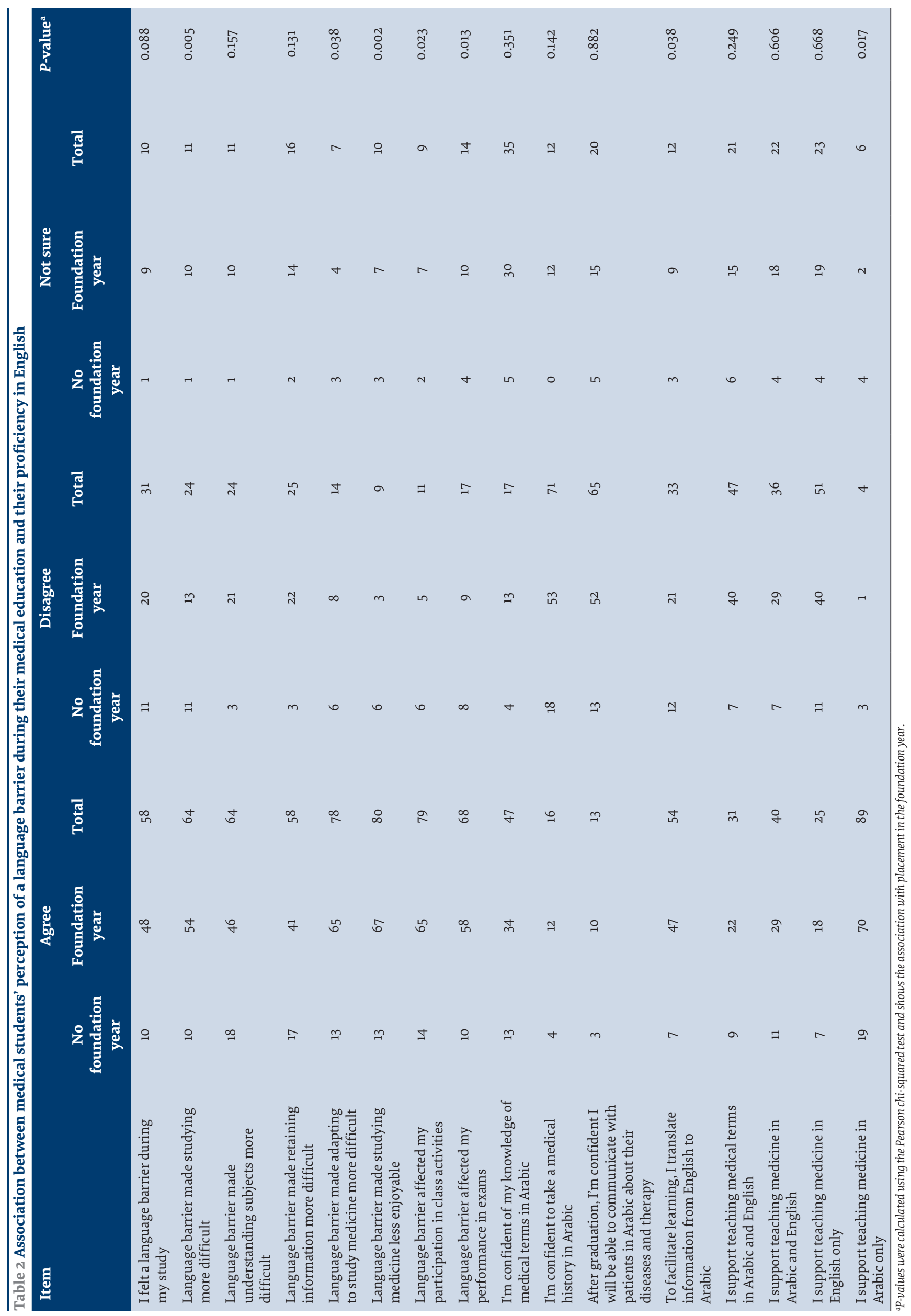


to communicate with patients in Arabic (66\%) (Table 2). No statistically significant differences were found between males and females in their response to the questions.

Regarding the students' preferred language of instruction, 51\% of them supported learning medicine in English only with no statistically significant difference in responses between students who had done a foundation year and those who had not $(P=0.668)$. Females were more in favour of learning medicine in English than males $(P=0.026)$. However, $36 \%$ and $47 \%$ of the students respectively supported the teaching of medicine and medical terminology in both Arabic and English, with no statistically significant difference in responses between students who had done a foundation year and those who had not ( $P=0.606$ and 0.249 respectively). Females were less receptive to learning medical terms in Arabic and English than males $(P=0.042)$. A small minority of the participants would prefer to learn medicine exclusively in Arabic with a statistically significant difference in responses between students who had done a foundation year and those who had not $(P=0.017)$.

\section{Discussion}

In various educational settings, when the language of instructions is different from the learner's mother tongue, the potential language barrier may adversely affect an individual's learning and professional life (7). This issue is of particular relevance to Arab countries since medical students whose first language is Arabic are taught medicine in English or French. By using a self-administered questionnaire, this study aimed to investigate the perception of final-year medical students of language difficulties at the Arabian Gulf University. Overall, our findings showed that most participants did not think that learning medicine in a second language affected their ability to manage the academic programme. Interestingly, however, just over a third of the students supported an approach where Arabic is combined with English in teaching. The latter observation may indicate that the students still believed in the importance of using Arabic in medical education, regardless of their English language skills and feeling of the language barrier.

Most of the students did not feel any language barrier. This finding was expected because most of them had not been required to do the foundation programme, indicating that their English skills were adequate. However, the association between feeling language barrier and students' English proficiency was not statistically significant. Similarly, while only a small percentage of participants thought that language issues affected their studies and performance in exams, this was significantly associated with English proficiency. A study in Egypt explored the perspectives of staff and students from years 1 to 6 on language barriers in medical education (8). Similar to our findings, $56.3 \%$ of the students did not consider using English an obstacle. Our finding that the students did not consider language a barrier was unexpected, since most them had been admitted to the college from governmental schools where Arabic is the teaching language. We believe that since these students were asked about their perceptions after six years of studying in English, they might have overcome the language difficulties over these years.

Most participants either did not know or were not sure if they knew medical terms in Arabic. Despite this, most of them felt confident to take a medical history from patients in Arabic and communicate with Arabic-speaking patients in their native language. These findings are contradictory since the students need to know medical terms in the patients' language in order to ask them questions while taking a medical history and also when they have explain the diagnosis or treatment to the patients. A study conducted in Egypt found that $70.6 \%$ of students preferred to learn how to taking a medical history in Arabic (8). Another study examined the confidence of medical students in communicating with Arabic-speaking patients after receiving training on communication skills in English (9). Only a quarter of the students were confident to take medical history in Arabic (9). Knowledge of medical terms in a patient's native language is an essential component of the doctor-patient interaction. Medical graduates who have been educated in a foreign language may face difficulties in communicating with their patients in their mother tongue.

When we explored students' preferred language of instruction, almost all of them rejected the suggestion of learning medicine exclusively in Arabic, although there was a statistically significant difference in responses between those who had done a foundation year and those who had not. Students' reluctance to learn medicine totally in Arabic is somewhat expected given the expected difficulties when they attempt international examinations. Previous attempts to deliver medical education completely in Arabic have faced difficulties (10). About half of the students supported learning medicine in English only while about a third supported a bilingual approach. Females were more likely to support learning medicine in English only and were less in favour of learning medical terms in both Arabic and English. The observed gender difference in preferred language of instruction is difficult to explain. Support of English only or a bilingual approach was not significantly associated with proficiency in English. Students' support of learning medicine in both Arabic and English may indicate their understanding of the importance of being competent in both Arabic and English terminology, perhaps to help them communicate with their patients in the future. These data indicate that a good proportion of the students preferred a bilingual approach that would allow them to learn medicine in their mother tongue and at the same time would not deprive them of learning in English, which is the most widely used language internationally.

Our study has some limitations. Firstly, some of the findings were contradictory. It would have been possible 
to explain these observations if a focus group discussion had been held where the participants could have explained more about their perceptions. Secondly, although the response rate of $70 \%$ was adequate, the investigators were not able to collect data on the views of the remaining $30 \%$. Refusal to participate in this study might be related to the student's language proficiency. That is, those students who did not agree to participate might have done so because their English was good. Thirdly, we considered placement in the foundation year as evidence that the student had poor English skills. Other more objective evidence might be more robust, such as scores in international English language proficiency exams.

\section{Conclusions}

We examined the perceptions of final-year medical students of the effect of studying medicine in English on their academic adaptation. Our findings showed that most of the students did not feel language barrier during their studies. Almost all of them rejected complete "Arabization" of medical education. However, a good proportion supported using Arabic for teaching medicine along with English. The findings of our study may help prompt medical schools in the Arab World to discuss the feasibility of also using Arabic in medical education as well as English.

\section{Acknowledgements}

We would like to thank the participating students, Dr Amer Al-Marabheh for the statistical analysis and Dr Kannan Sridharan for proofreading the manuscript.

Funding: None.

Competing interests: None declared.

\section{Barrières linguistiques aux études de médecine en anglais : perception des étudiants de dernière année de médecine à l'Université du Golfe arabique \\ Résumé}

Contexte : L'anglais est la langue d'enseignement de nombreuses écoles de médecine du monde arabe. Son utilisation pourrait créer une barrière linguistique et avoir une incidence négative sur l'apprentissage lors des études, et plus tard, sur la vie professionnelle.

Objectifs : La présente étude a examiné la perception des étudiants arabes inscrits en dernière année de médecine d'une éventuelle barrière linguistique et de son effet sur leur apprentissage et leurs résultats universitaires ainsi que leur préférence linguistique pour l'enseignement de la médecine.

Méthodes : Tous les étudiants de dernière année de médecine ( $n=142,62 \%$ de femmes) à l'Université du Golfe arabique (Bahreïn) ont été invités à répondre à un questionnaire d'auto-évaluation. Les différences de réponses selon le niveau d'anglais et le sexe ont été évaluées.

Résultats : Sur les 142 étudiants, 99 (70 \%) ont répondu au questionnaire. La plupart des étudiants ne percevaient pas de barrière linguistique, indépendamment de leur niveau d'anglais $(p=0,088)$. La majorité des personnes interrogées ne pensaient pas que les problèmes linguistiques rendaient l'apprentissage plus difficile, malgré un contraste significatif dans les réponses entre les étudiants considérés comme avancés en anglais et ceux qui l'étaient moins ( $p=0,005)$. La plupart des étudiants ( $82 \%$ ) ne connaissaient pas ou n'étaient pas sûrs des termes médicaux en arabe, mais 66 \% d'entre eux pensaient néanmoins être en mesure de communiquer avec les patients en arabe. Près de la moitié des étudiants (51\%) approuvaient l'anglais comme langue exclusive d'apprentissage de la médecine, tandis que 36 \% étaient en faveur d'un apprentissage en arabe et en anglais.

Conclusions : La plupart des étudiants estimaient que l'enseignement en anglais était sans incidence sur leur apprentissage et leurs résultats universitaires. Cependant, une proportion non négligeable était en faveur d'un enseignement de la médecine en arabe et en anglais.

$$
\begin{aligned}
& \text { آراء طلاب الطب في السنة النهائية في جامعة الخليج العربي بشأن الحواجز اللغوية التي تعوق دراسة الطب باللغة } \\
& \text { الإنجحليزية } \\
& \text { ياسين تيّم، أحمد الشمري، نوفئ البلوي، مروة شريف } \\
& \text { الخالاصنة }
\end{aligned}
$$

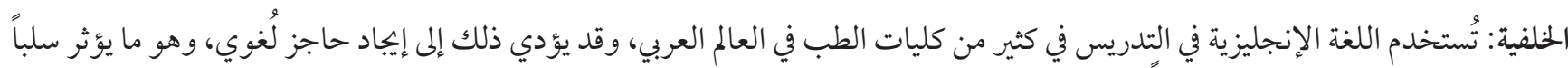

$$
\begin{aligned}
& \text { على قدرة الفرد على التعلم ويؤثر لاحقاً على حياته المهنية. }
\end{aligned}
$$


الأهداف: تناولت هذه الدراسة آراء الطلاب العرب في السنة النهائية بكلية الطب بشأن الحاجز اللغوي وتأثيره على تحصيلهم وأدائهم الأكاديمي، وبشأن اللغة التي يفضلونها في هذه التي التعليم الطبي.

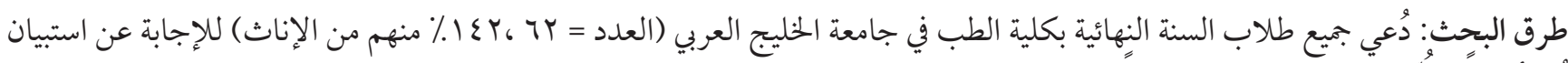

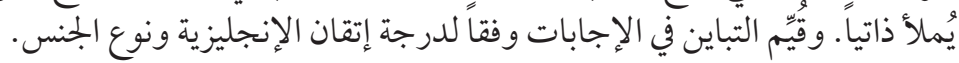

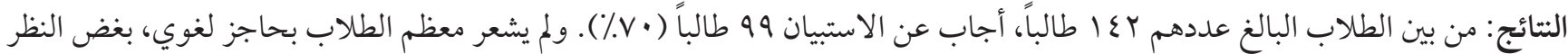

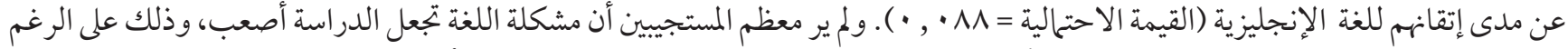

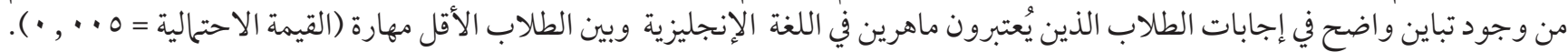

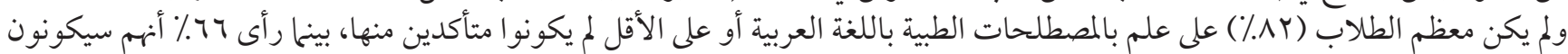

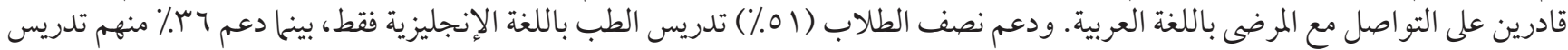
الطب باللغتين العربية و الإنجليزية.

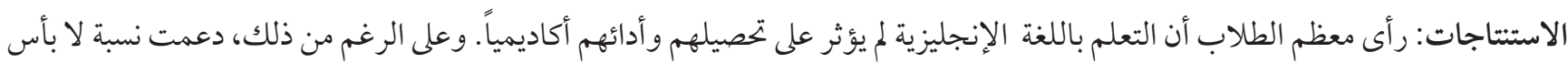
هها تدريس الطب باللغتين العربية و الإنجليزية.

\section{References}

1. Hamdy H, Telmesani AW, Al Wardy N, Abdel-Khalek N, Carruthers G, Hassan F, et al. Undergraduate medical education in the Gulf Cooperation Council: a multi-countries study (Part 1). Med Teach. 2010;32(3):219-24. https://doi. org/10.3109/01421590903389108

2. Holtzman KZ, Swanson DB, Ouyang W, Dillon GF, Boulet JR. International variation in performance by clinical discipline and task on the United States medical licensing examination step 2 clinical knowledge component. Acad Med. 2014;89(11):1558-62. https://doi.org/10.1097/ACM.0000000000000488

3. Mann C, Canny B, Lindley J, Rajan R. The influence of language family on academic performance in year 1 and 2 MBBS students. Med Educ. 2010;44(8):786-94. https://doi.org/10.1111/j.1365-2923.2010.03711.x

4. Almoallim H, Aldahlawi S, Alqahtani E, Alqurashi S, Munshi A. Difficulties facing first-year medical students at Umm Alqura University in Saudi Arabia. East Mediterr Health J. 2012;16(12):1272-7.

5. Kim JJ, Kim MS, Lee JS, Lee DS, Lee MC, Kwon JS. Dissociation of working memory processing associated with native and second languages: PET investigation. Neuroimage. 2002;15(4):879-91. https://doi.org/10.1006/nimg.2001.1025

6. Alnasir FA, Jaradat AA. The effectiveness of AGU-MCAT in predicting medical student performance in year one of the College of Medicine of the Arabian Gulf University. Educ Health (Abingdon). 2011;24(2):447.

7. Henderson D, McGrath PD, Patton MA. Experience of clinical supervisors of international medical graduates in an Australian district hospital. Aust Health Rev. 2017;(4):365-71. https://doi.org/10.1071/AH15094

8. Sabbour SM, Dewedar SA, Kandil SK. Language barriers in medical education and attitudes towards Arabization of medicine: student and staff perspectives. East Mediterr Health J. 2012;16(12):1263-71.

9. Mirza DM, Hashim MJ. Communication skills training in English alone can leave Arab medical students unconfident with patient communication in their native language. Educ Health (Abingdon). 2010;23(2):450.

10. Mahmdani AA, Abdel Rahman SH. Evaluating the impact of Arabization on medical students' acquisition, Gezira University, Sudan. East Mediterr Health J. 2006;12(Suppl 2):S223-9. 